\title{
Rituximab pharmacokinetics in ascites and serum in the treatment of follicular lymphoma with massive ascites
}

\author{
Yuki Hiroshima $\cdot$ Katsushi Tajima $\cdot$ Yousuke Shiono • \\ Ikuko Suzuki • Kei Kouno • Masakazu Yamamoto• \\ Yuichi Kato • Takeo Kato
}

Received: 28 September 2011 / Accepted: 9 January 2012 /Published online: 28 January 2012

(C) The Author(s) 2012. This article is published with open access at Springerlink.com

\begin{abstract}
Dear Editor,
Rituximab is an effective and safe monoclonal antibody in the treatment of CD20+ malignant lymphoma [1]. In patients with massive pleural effusions or ascites associated with lymphoma, it remains unclear whether rituximab should be administered not only by intravenous infusion but also via the intraperitoneal route [2-4]. We studied the association of rituximab concentration and disappearance of lymphoma cells in ascites after intravenous application. The concentration of rituximab was low $3 \mathrm{~h}$ after infusion, but increased $24 \mathrm{~h}$ later. Flow cytometry (FCM) analyses revealed several CD20+ lymphoma cells at $3 \mathrm{~h}$ which completely disappeared $24 \mathrm{~h}$ later. These observations indicated that rituximab antibody may be resorbed from the circulation to the peritoneal cavity and may have an anti-tumor role in ascites. We report a patient who developed massive ascites due to a follicular lymphoma who was treated with rituximab.

A 40-year-old male presented with generalized lymphadenopathy in 1999. Pathology of the lymph node revealed a grade-2 follicular B cell lymphoma with the chromosomal abnormality $t(14 ; 18)$. He received combination chemotherapy with cyclophosphamide, doxorubicin, vincristine, and prednisone (CHOP). After three cycles of CHOP, his symptoms promptly resolved. He discontinued hospital visits from 2001 onwards.
\end{abstract}

Y. Hiroshima $\cdot$ K. Tajima $(\bowtie) \cdot$ Y. Shiono $\cdot$ I. Suzuki $\cdot$ K. Kouno

M. Yamamoto $\cdot$ Y. Kato $\cdot$ T. Kato

Third Department of Internal Medicine,

Yamagata University School of Medicine,

2-2-2, Iidanishi, Yamagata-shi,

Yamagata 990-9585, Japan

e-mail: tajima@nirs.go.jp
This patient presented again to our hospital with generalized lymphadenopathy, abdominal discomfort, and massive ascites in 2008 (Fig. 1a). Biopsy of the left inguinal lymph node showed regrowth of a CD20+ grade- 2 follicular lymphoma. A bone marrow specimen exhibited several atypical lymphocytes with $t(14 ; 18)$ by fluorescence in situ hybridization (FISH). Aspiration of ascites demonstrated CD20 + B cells and CD3+ T cells by FCM. FISH analyses showed $t(14 ; 18)$ cells $(16 \%)$ in ascites. His symptoms (in particular, abdominal discomfort due to ascites) persisted despite the first cycle of rituximab plus CHOP (R-CHOP). We supposed that the concentration of rituximab in ascites by intravenous infusion was not sufficient to elicit an effect. Therefore, upon secondary therapy, we administered only rituximab without $\mathrm{CHOP}$ by intravenous infusion to examine the relationship between rituximab concentration and the disappearance of lymphoma cells in ascites. Concentrations of rituximab in ascites and serum were 0.8 and $98.1 \mu \mathrm{g} / \mathrm{mL}$, respectively, $3 \mathrm{~h}$ after infusion, and 3.3 and $21.7 \mu \mathrm{g} / \mathrm{mL}$ $24 \mathrm{~h}$ later. Massive ascites was resolved after 3 days of infusion (Fig. 1b). FCM analyses demonstrated that CD20+ lymphoma cells (22.4\%) in ascites at $3 \mathrm{~h}$ (Fig. 1c) completely disappeared $24 \mathrm{~h}$ later (Fig. 1d). The patient received six cycles of R-CHOP and was doing well.

A few reports have suggested that lymphoma with massive effusions or ascites demands local therapies such as intraperitoneal administration of rituximab as well as systemic chemotherapy [2-4]. Unfortunately, those studies did not measure the level of rituximab in ascites, effusions, or serum before and after local instillation. Thus, whether local (not systemic) administration is required for the management of ascites or effusions is not known. The mechanism of 
Fig. 1 CT of the abdomen before and after intravenous instillation of rituximab. a Massive ascites before infusion. b Three days after infusion, ascites was resolved. Changes in lymphoma cells doublepositive for CD19+/20+ cells in ascites by FCM analyses. c Three hours after infusion, lymphoma cells $(22.4 \%)$ were present in ascites. d At $24 \mathrm{~h}$, double-positive cells completely disappeared
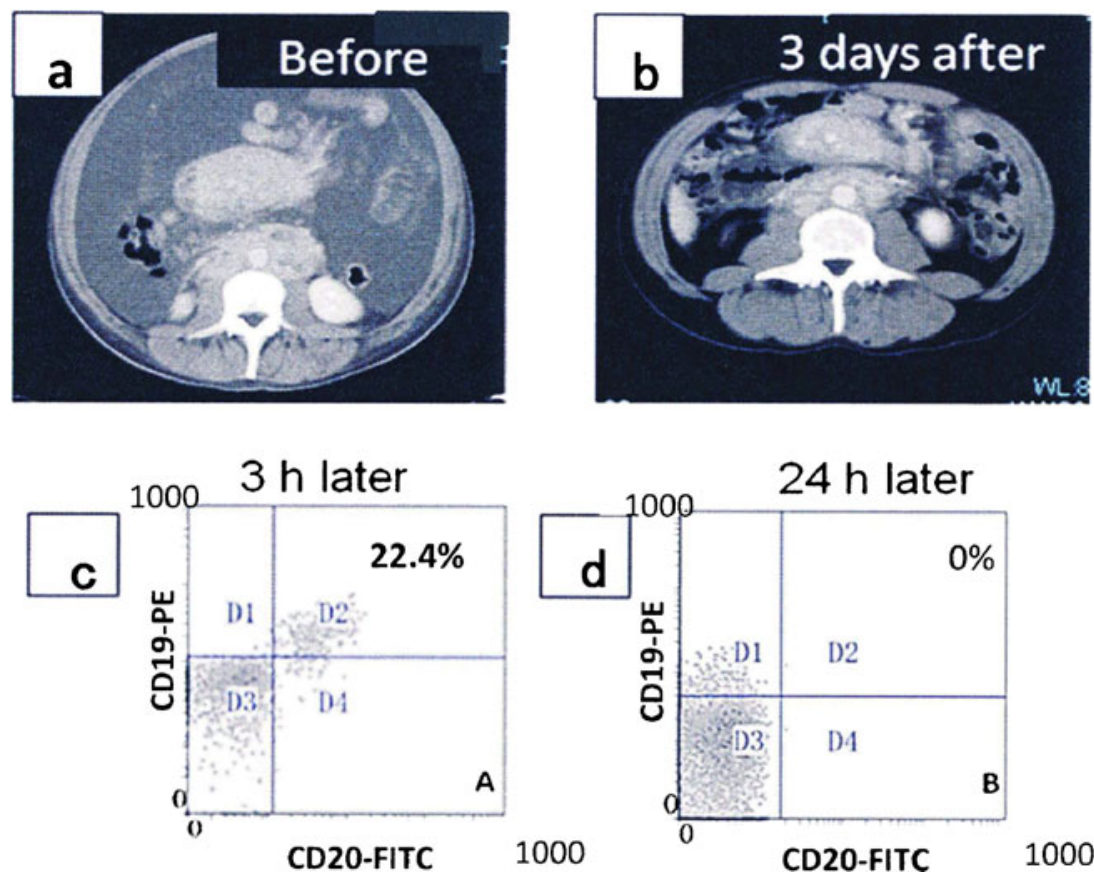

action of rituximab is incompletely understood. However, rituximab is thought to induce cell destruction, including apoptosis, complement-dependent cytotoxicity (CDCC), and antibody-dependent cellular cytotoxicity (ADCC) [5]. In in vitro studies, rituximab induced direct cytotoxicity against the RAJI CD20+-expressing lymphoma cell line at $>0.1 \mu \mathrm{g} / \mathrm{mL}$ [5]. That report showed that, after 4-h incubation in human serum, direct cytotoxicity was not evident, but after 3 days of culture, remarkable combined direct cytotoxicity and CDCC was induced [5]. In our case, we identified a rituximab concentration in ascites $>0.1 \mu \mathrm{g} / \mathrm{mL} 3$ and $24 \mathrm{~h}$ later only by intravenous administration. The remaining CD20+ lymphoma cells $(22.4 \%)$ in ascites at $3 \mathrm{~h}$ completely disappeared $24 \mathrm{~h}$ later. These findings suggested that rituximab in ascites may mediate not only direct cytotoxicity against lymphoma cells, but also CDCC or ADCC induced by serum and several CD3+ cells in ascites as effector cells. The efficacy of rituximab may be dependent upon the relative ratio of effector cells (CD3+ lymphocytes) to target cells (CD20+ lymphoma cells) in ascites. However, the exact mechanism of cytotoxicity remains unclear. The pharmacokinetics and efficacy of rituximab should be investigated in a larger study population.
Open Access This article is distributed under the terms of the Creative Commons Attribution Noncommercial License which permits any noncommercial use, distribution, and reproduction in any medium, provided the original author(s) and source are credited.

\section{References}

1. Berinstein NL, Grillo-Lopez AJ, White CA, Bence-Brucker I, Maloney D, Czuczman M, Green D, Rosenberg J, McLaughlin P, Shen D (1998) Association of serum rituximab (IDEC-C2B8) concentration and antitumor response in the treatment of recurrent low-grade or follicular non-Hodgkin's lymphoma. Ann Oncol 9:995-1001

2. Ng T, Pagliuca A, Mufti GJ (2002) Intraperitoneal rituximab: an effective measure to control recurrent abdominal ascites due to nonHodgkin's lymphoma. Ann Hematol 81:405-406

3. Schmidt HH, Renner H, Linkesch W (2004) Intrapleural instillation of rituximab for the treatment of malignant pleural effusions in NHL. Hematologica 89:133-134

4. Crysandt M, Neumann B, Das M, Engelbertz V, Bendel M, Galm O, Osieka R, Jost E (2007) Intraperitoneal application of rituximab in refractory mantle cell lymphoma with massive ascites resulting in local and systemic response. Eur J Haematol 79:546-549

5. Flieger D, Renoth S, Beier I, Sauerbruch T, Wolf IS (2000) Mechanism of cytotoxicity induced by chimeric mouse monoclonal antibody IDEC-C2B8 in CD20-expressing lymphoma cell lines. Cell Immunol 204:55-63 